\title{
Variability in Rainfall for Aravalli Range of Rajasthan, India
}

\author{
Sunil Kumar Yadav*, Shraddha Rawat and Shweta Gautam \\ Department of Environmental Science \& NRM, College of Forestry, SAM Higginbottom \\ University of Agriculture, Technology and Sciences Allahabad - 211007 (U.P.), India \\ *Corresponding author
}

\section{A B S T R A C T}

\begin{tabular}{|l|}
\hline Ke y w or d s \\
Rainfall, Aravalli \\
Rang, Ajmer
\end{tabular}

\section{Introduction}

The state Rajasthan receive least rainfall where the monsoon sets in the last but begin to withdrawn early. The state broadly divided into arid, semi-arid and sub humid region on the basis of rainfall intensity. The rainfall distribution in Rajasthan not even and varies considerably region to region and year to year. The presence of Aravalli's range leads to regional climate variability. Many researchers have attempted to study the rainfall analysis for crop planning Archer and Fowler (2004), have studied variation of precipitation in spatial and temporal scale in the upper Indus Basin and reported that winter precipitation is highly correlated spatially across the basin and over the last century, there is no statistically significant long term trend in annual or seasonal precipitation time series. Krishnakumar et al., (2008) studied temporal variation in monthly, seasonal and annual rainfall over Kerala, India and revealed the significant decrease in southwest monsoon rainfall while increase in post monsoon season. Parthasarathi and Dhar (1975) reported that the rainfall over India was increased from $1431 \mathrm{~mm}$ to $1960 \mathrm{~mm}$. The feature of rainfall variability will help farmers to proper planning of crop. Therefore it is of interest to examine the variability of rainfall over aravalli's range of Rajasthan.

\section{Materials and Methods}

The rainfall data for the 7 districts of aravalli range Rajasthan was taken from water resources department (water.rajasthan.gov.in) 
for period 1986-2016. The 31 years data was future used for the rainfall variability analysis. Time series analysis such as standard deviation, coefficient of variation and mean rainfall.

\section{Methodology}

\section{Mean rainfall}

The amount of rainfall collected by a given rain gauge in $24 \mathrm{hrs}$ is known as daily rainfall $(\mathrm{mm}$ or $\mathrm{cm})$ and the amount collected in one year in known as annual rainfall. The mean of the annual rainfall over of 35 years (in India) is known as mean annual rainfall (average annual rainfall or normal annual rainfall).

Mean Annual Rainfall $=\frac{\text { Total } \text { Rainf all }}{\text { Number of Yeras }}$

\section{Standard Deviation (SD)}

It is defined as the square root of the mean of the squares of deviations of the rainfall value from the arithmetic mean of all such rainfall. It is a measure of variability or the scatter or the dispersion about the mean value. It is given by the following formula.

$$
S D(\sigma)=\sqrt{\frac{\sum(X-\bar{X})^{2}}{n-1}}
$$

$\mathrm{X}=$ Rainfall

$\bar{X}=$ Mean rainfall

$\mathrm{n}=$ Number of year

\section{Coefficient of variation}

$\mathrm{CV}$ is estimated in order to know the amount of variation in rainfall. It is calculated by dividing the SD of rainfall by its mean variability by $\mathrm{CV}$ presented in percentage.

$\mathrm{cV} \%=\frac{\text { Standard Deviation }}{\text { Mean }} \times 100$
The greater the $\mathrm{CV}$, the lesser the dependability of receiving rainfall. Considering the annual CV, the IMD is using the following criteria for assessing the rainfall in a particular area.

Normal $=-19$ to $19 \%$ of annual normal rainfall.

Deficit $=-20$ to $-59 \%$ of annual normal rainfall.

Scarce $=-60 \%$ and above of annual normal rainfall

\section{Results and Discussion}

The results of this study have been presented in different subheadings as following:

\section{Decadal Rainfall analysis}

For this the 31years (starting from 1986 to 2016) rainfall data has been divided into 3 decades viz 1986-1995, 1996-2005 and 20062016 respectively district wise. In table 1 the mean and coefficient of variation of these different decades has been presented.

The lowest CV was found for the Rajsamand district for the first and second decade, while for the last decade (2006-2016) the CV was least in case of Udaipur. For first, second and third decades the least rainfall was observed in Alwar, Rajsamand and Ajmer respectively. While there is variation in maximum amount of rainfall in three decades.

The result of the study shows that the coefficient of variation during the south west monsoon was highest in Bhilwara $(70.40 \%)$ and Ajmer (65.69\%) district, while the lowest CV was found in the Alwar district (37.33\%). Overall the range of $\mathrm{CV}$ for the 7 districts of aravalli range Rajasthan varied from $37.33 \%$ to $70.40 \%$ (Table 2). 
Table.1 Decadal Rainfall Variability in Aravalli Range Districts of Rajasthan

\begin{tabular}{|l|c|c|c|c|c|c|}
\hline District & $\mathbf{1 9 8 6 - 1 9 9 5}$ & $\mathbf{1 9 9 6 - 2 0 0 5}$ & $\mathbf{2 0 0 6 - 2 0 1 6}$ & $\mathbf{1 9 8 6 - 1 9 9 5}$ & $\mathbf{1 9 9 6 - 2 0 0 5}$ & $\mathbf{2 0 0 6 - 2 0 1 6}$ \\
\hline & $\begin{array}{c}\text { Mean } \\
\text { Rainfall }\end{array}$ & $\begin{array}{c}\text { Mean } \\
\text { Rainfall }\end{array}$ & $\begin{array}{c}\text { Mean } \\
\text { Rainfall }\end{array}$ & CV & CV & CV \\
\hline Sirohi & 562.71 & 533.13 & 645.85 & 67.05 & 41.71 & 44.63 \\
\hline Udaipur & 564.42 & 573.30 & 724.18 & 41.09 & 22.69 & 20.71 \\
\hline Rajsamand & 542.81 & 476.60 & 678.91 & 23.96 & 20.78 & 27.51 \\
\hline Bhilwara & 710.17 & 606.11 & 680.29 & 29.94 & 35.06 & 33.80 \\
\hline Jaipur & 558.87 & 544.90 & 631.24 & 27.86 & 40.18 & 42.21 \\
\hline Ajmer & 519.89 & 513.78 & 546.16 & 37.01 & 44.88 & 23.79 \\
\hline Alwar & 519.06 & 654.48 & 812.82 & 39.44 & 49.09 & 25.32 \\
\hline
\end{tabular}

Table.2 Variability of SW monsoon of aravalli range regions of Rajasthan

\begin{tabular}{|l|c|c|c|c|c|c|c|}
\hline Months & Sirohi & Udaipur & Rajsamand & Bhilwara & Jaipur & Ajmer & Alwar \\
\hline June & 56.95 & 71.83 & 70.63 & 53.7 & 61.1 & 46.6 & 88.5 \\
\hline July & 197.17 & 211.54 & 193.4 & 246.1 & 162.9 & 188.3 & 174.7 \\
\hline August & 192.22 & 179.64 & 183.22 & 252.3 & 171.5 & 215.2 & 203 \\
\hline September & 90.99 & 113.91 & 70.73 & 67.5 & 80.1 & 66.7 & 109.8 \\
\hline Total & 537.33 & 576.92 & 517.98 & 619.6 & 475.6 & 516.8 & 576 \\
\hline SD & 71.1 & 63.1 & 68.04 & 109.06 & 56.41 & 84.88 & 53.76 \\
\hline CV & 52.93 & 43.75 & 52.54 & 70.40 & 47.44 & 65.69 & 37.33 \\
\hline
\end{tabular}

Table.3 Variability of NE monsoon of aravalli range regions of Rajasthan

\begin{tabular}{|l|c|c|c|c|c|c|c|}
\hline Months & Sirohi & Udaipur & Rajsamand & Bhilwara & Jaipur & Ajmer & Alwar \\
\hline October & 17.49 & 17.03 & 18.48 & 6.5 & 11.8 & 17.2 & 12.7 \\
\hline November & 6.23 & 3.93 & 7.61 & 5.1 & 3.4 & 3.4 & 3.1 \\
\hline December & 1.18 & 1.12 & 2.14 & 3 & 1.5 & 2 & 4 \\
\hline Total & 24.9 & 22.08 & 28.23 & 14.6 & 16.7 & 22.6 & 19.8 \\
\hline SD & 8.35 & 8.49 & 8.31 & 1.76 & 5.48 & 8.4 & 5.3 \\
\hline CV & 100.60 & 115.35 & 88.31 & 36.21 & 98.56 & 111.55 & 80.30 \\
\hline
\end{tabular}


From the Table 2 it may be concluded that the there is high variation in the amount of rainfall in different districts of the aravalli range Rajasthan. During SW monsoon the Bhilwara district received the highest amount of rainfall $(619.6 \mathrm{~mm})$ and Jaipur received $475.6 \mathrm{~mm}$ of rainfall Similar kind of study had been conducted by Biradar et al., (2011), Which suggested that the analyzed daily rainfall data of thirty fours (1976-2009) for establishing the long term averages of monthly, seasonal and annual and its variability. The mean annual rainfall was $937.3 \mathrm{~mm}$ with coefficient of variation of 22.2 per cent indicated that the annual rainfall was more or less stable over the years. The season wise per cent contribution to annual rainfall was $1.6,8.4,75.5$ and 14.5 per cent of winter, summer, monsoon and post monsoon seasons, respectively.

The result of the study shows that the coefficient of variation during the north east monsoon was highest in Udaipur (115.35\%) and Ajmer (111.55\%) district, while the lowest $\mathrm{CV}$ was found in the Bhilwara district (36.21\%). Overall the range of $\mathrm{CV}$ for the 7 districts of aravalli range Rajasthan varied from $36.21 \%$ to $115.35 \%$ (Table 3). From the Table 3 it may be concluded that the there is high variation in the amount of rainfall in different districts of the aravalli range Rajasthan.

During NE monsoon the Rajsamand district received the highest amount of rainfall $(28.23 \mathrm{~mm})$ and Bhilwara received only $14.6 \mathrm{~mm}$ of rainfall Similar kind of study had been conducted by Kothari et al., (2007), reported a comprehensive study on rainfall data of Bhilwara district, Rajasthan state for a period of 45 years were analyzed from two approaches viz.; 'Meteorological' approach and 'Onset of monsoon' approach. The results revealed considerable difference in rainfall characteristics with respect to length of growing period, water surplus/deficit and probability of intervening dry spells due to these approaches.

In this study different months of the data for the period (1986 - 2016) has been used to evaluate rainfall variability of different districts of aravalli range regions of Rajasthan. It was found that the SW monsoon rainfall is higher at Bhilwara district followed by Udaipur and Alwar. The mean SW monsoon rainfall is lowest at Jaipur. The NE monsoon rainfall is higher at Rajsamand district. The mean NE monsoon rainfall is lowest at Bhilwara. The monthly values of $\mathrm{CV}$ during monsoon months were lower when compared to other months. However the lowest values of $\mathrm{CV}$ were in the month of July and August. In month of August rainfall occurred due to cyclonic activity. Mainly when the $\mathrm{CV}$ for the $\mathrm{SW}$ monsoon rainfall was examined, it was found be the least at Alwar and highest in Bhilwara and the CV for the NE monsoon rainfall was examined, it was found be the least at Bhilwara and highest in Udaipur.

\section{References}

Archer, D.R. and Fowler, H.J. (2004) Spatial and temporal variations in precipitation in the Upper Indus Basin, global teleconnections and hydrological implications. Hydrol. Earth Syst. Sci., 8, 47-61

Biradar, Vishwanath, Biradar, Baswaraj and Arunkumar, B. (2011). Annual and seasonal rainfall variability of Bidar taluka (Karnataka). Internat. J. agric. Sci., 7(1): 183-186.

Biswas, B.C. and Khambeta, N.K. (1974) Distribution of short period rainfall over dry farming tract of Maharashtra. $J$. Maharashtra Agric. Univ., 12: 157-168.

Gupta, S. K., Babu, R. and Tejwani, K. G. (1975) Weekly rainfall of India for 
planning cropping programme. Soil Conserv. Digest., 3 (1): 31-36.

Kothari, A.K., Kumar, V., Jain,.P.M., Purohit,.R.C. 2007. Dynamic crop planning for enhancing the crop productivity under rainfed conditions. Journal of Agricultural Engineering New Delhi. 44(3): 55-62.

Krishnakumar et al., (2008) Rainfall trends in twentieth century over Kerala, India, Atmospheric Environment, Volume 43(11) pp: 1940-1944.

Kumar, K. (2008) Rainfall trends in twentieth century over Kerala, India, Atmospheric Environment, Volume 43(11) pp: 19401944.

Manjunath, H., Manjunath, P.H., Sherikar, S.B. and Shreelaxmi (2014) Decadal rainfall pattern characterization and profiling of rainfall parameters over western Yadgir district, Karnataka. B.Tech Thesis, University of Agricultural Sciences, Raichur Karnataka (India).

Parthasarathy, B and Dhar, O.N. 1975 Trend analysis of annual Indian rainfall. Hydrologic. Sci. J., 26 (20): 257-260.

Rai, S.K., Kumar, S., Rai, A.K., Satyapriya and Palsaniya, D.R. (2014) Climate
Change, Variability and Rainfall Probability for Crop Planning in Few Districts of Central India. Atmospheric and Climate Sciences, 4, 394-403.

Rajbanshi, J. (2015) Rainfall distribution and its spatial and temporal variability over damodar basin under climate change scenario (1901-2002), IOSR Journal of Environmental Science, Toxicology and Food Technology. Volume 9, Issue 9 Ver. II, PP 95-104.

Ramdurg, H., Reddy, G.V., Srinivasa, Krishnamurthy, D., Babu, B., Maheshwara and Nemichandrappa, M. (2015) Weekly rainfall variability and probability analysis for resource planning at Hadagali, Karnataka. Internat. J. Agric. Engg., 8(2): 255-260.

Sarkar, R.P. and Biswas, B.C. (1988) A new approach to agroclimatic classification to find out crop potential. Mausam. 39 (4): 343-358.

Wadood A. and Kumari P. (2009) Impact of climate change on jharkhand agriculture: mitigation and adoption, ISPRS Archives XXXVIII-8/W3 Workshop Proceedings: Impact of Climate Change on Agriculture.

\section{How to cite this article:}

Sunil Kumar Yadav, Shraddha Rawat and Shweta Gautam. 2018. Variability in Rainfall for Aravalli Range of Rajasthan, India. Int.J.Curr.Microbiol.App.Sci. 7(07): 4339-4343. doi: https://doi.org/10.20546/ijcmas.2018.707.505 